\title{
EFFECTS OF VARIED PROCESS PARAMETERS ON FROTH FLOTATION EFFICIENCY: A CASE STUDY OF ITAKPE IRON ORE
}

\author{
S. Akande ${ }^{1}$, E. O. Ajaka ${ }^{2}$, 0. O. Alabi ${ }^{3}$ and T. A. Olatunji, ${ }^{4}$ \\ 1, 2, Department of Mining Engineering, Federal Univ. OF TeChnology, AkURe, Ondo State, Nigeria \\ 3,4, Dept. of Met. \& Materials Engineering, Federal Univ. of TeChnology, Akure, Ondo State, Nigeria \\ Email addresses: ${ }^{1}$ mrsserahak@gmail.com, 2 eoajaka@futa.edu.ng, \\ 3 oladunni69alabi@yahoo.com, ${ }^{4}$ olatunjitopeamos@gmail.com
}

\begin{abstract}
The dire need for Itakpe iron ore concentrates of appreciable iron content meets for smelting operation necessitated this study. Core samples of the iron ore sourced from Itakpe, Kogi State, Nigeria were prepared for petrological analysis followed by chemical and particle size analyses. Froth flotation was done using different collectors at varying particle sizes and pH values. Characterization studies carried out revealed that Itakpe iron ore is a lean ore assaying $36.18 \%$ $\mathrm{Fe}_{2} \mathrm{O}_{3}$ and contains predominantly quartz, sillimanite, and haematite. Its liberation size lies favourably at $75 \mu \mathrm{m}$. Processing the ore by froth flotation yielded appreciable enrichment. Optimal recovery ( 92\%) was achieved using potassium amyl xanthate (PAX) at pH 11 for fine feed sizes $(<125 \mu \mathrm{m})$ yielding iron concentrate assaying $67.66 \% \mathrm{Fe}_{2} \mathrm{O}_{3}$. Thus, processing at this set-ofconditions is recommended for the industrial production of more enriched Itakpe iron ore concentrates.
\end{abstract}

Keywords: Process parameters, Froth flotation, Efficiency, Itakpe iron ore

\section{INTRODUCTION}

Ores are composed of varieties of minerals, among which the mineral of interest lies. Prior to the processing of these ores, it is pertinent to have a grasp of their mineral entities, morphology, the spatial distribution of mineral constituents, particle size distribution, and other attributes [1]. Therefore, a detailed mineralogical characterization does not only reveals economic minerals but also gangue minerals which are deterrent to the exploitation and processing of the ore to salable product [2]. Onpremise of the distinctive physical/physicochemical properties of these minerals, the desired mineral(s) can be liberated through successive comminution and subsequently, separated via methods such as magnetic, gravity, and froth flotation [3].

The nature and surface properties of minerals affect to a great extent their susceptibility to froth flotation. These properties are exploited to facilitate the liberation of valuable minerals from gangue minerals
[4]. Froth flotation is a wet separation process that segregates mineral particles in a slurry [5]. It is often referred to as a physicochemical process that employs the use of chemical reagents to alter the surface properties of mineral particles towards selective separation [6]. Consequently, the surfaces of selected mineral particles are made hydrophobic (water repellent) and become attached to air bubbles introduced in the pulp via aeration [7]. These are carried to the froth layer and skimmed off while leaving the hydrophilic (wetted) mineral particles depressed in the pulp. Froth flotation is undoubtedly the most versatile mineral separation technique employed in the mineral industry to treat sulphide minerals (such as Galena, Chalcopyrite, etc.), oxide minerals (such as haematite, cassiterite, etc.) and so on; since the mineralogical constituents of these minerals possess distinct surface properties [8].

The enormous growth of industrialization from the eighteenth century until this day has been ascribed

* Corresponding author, tel: +234- $706-072-9133$ 
to the discovery of metals especially iron and the mineral industry as a whole [9]. As the demand for iron concentrate increases globally, there is a need to assess and develop flotation conditions that would best beneficiate viable deposits towards optimal recovery [10]. Of such deposits is Itakpe, Kogi State, Nigeria; which has a total estimated reserve of about 182.5 million metric tonnes and consists mainly of quartzite with magnetite and hematite [11, 12]. The Itakpe deposit has been developed to supply iron ore concentrates to Ajaokuta steel plant and the Delta steel plant, Aladja. The deposit is being processed using magnetic and gravity methods of mineral processing while the flotation plant remains underdeveloped [13], thus justifying the need for this research.

According to Wills and Napier-Munn [8], in view of assessing the metallurgical performance/efficiency of a process, concentrate grade and recovery are prominent parameters employed. Although, the economic viability of the process depends not only on these parameters but other factors such as smelter's cost are considered [14]. However, froth flotation is a process system whose efficiency depends on the interplay of certain process parameters. It is therefore pertinent to take into consideration these parameters during froth flotation operations. Such parameters include feed rate, $\mathrm{pH}$, collector type, and particle size; which automatically cause changes in other parts of the system such as percent recovery, flotation rate, and pulp density [15]. Therefore, this research aimed to characterize Itakpe iron ore, investigate the effects of varying collectors, particle sizes, and $\mathrm{pH}$ values on froth flotation efficiency and also establish the best process parameters that yield optimal recovery.

\section{METHODOLOGY}

A representative chart of methodologies employed to achieve the aim of this research is presented in Figure 1.

\subsection{Material Sourcing and Preparation}

Fifty (50) $\mathrm{kg}$ sample of the crude ore was sourced from the deposit located at Itakpe, Kogi State, Nigeria having geological co-ordinates of latitude $7^{\circ} 36^{\prime} 52 \mathrm{~N} N$ and longitude $6^{\circ} 19^{\prime} 7^{\prime \prime} \mathrm{E}$. The sample was crushed using a sledgehammer to $10 \mathrm{~mm}$ size and charged into the Denver laboratory jaw crusher (Model: Denver D12) for further reduction to $2 \mathrm{~mm}$. Then, thorough mixing was carried out to obtain a homogenized sample. The homogenized sample was then ground to three particle sizes; $63 \mu \mathrm{m}, 75 \mu \mathrm{m}$, and $125 \mu \mathrm{m}$. These sizes were selected because they fall within $250-45 \mu \mathrm{m}$, as documented by Wills and Napier-Munn, which depicts the favourable size range for the flotation of iron ores [8].

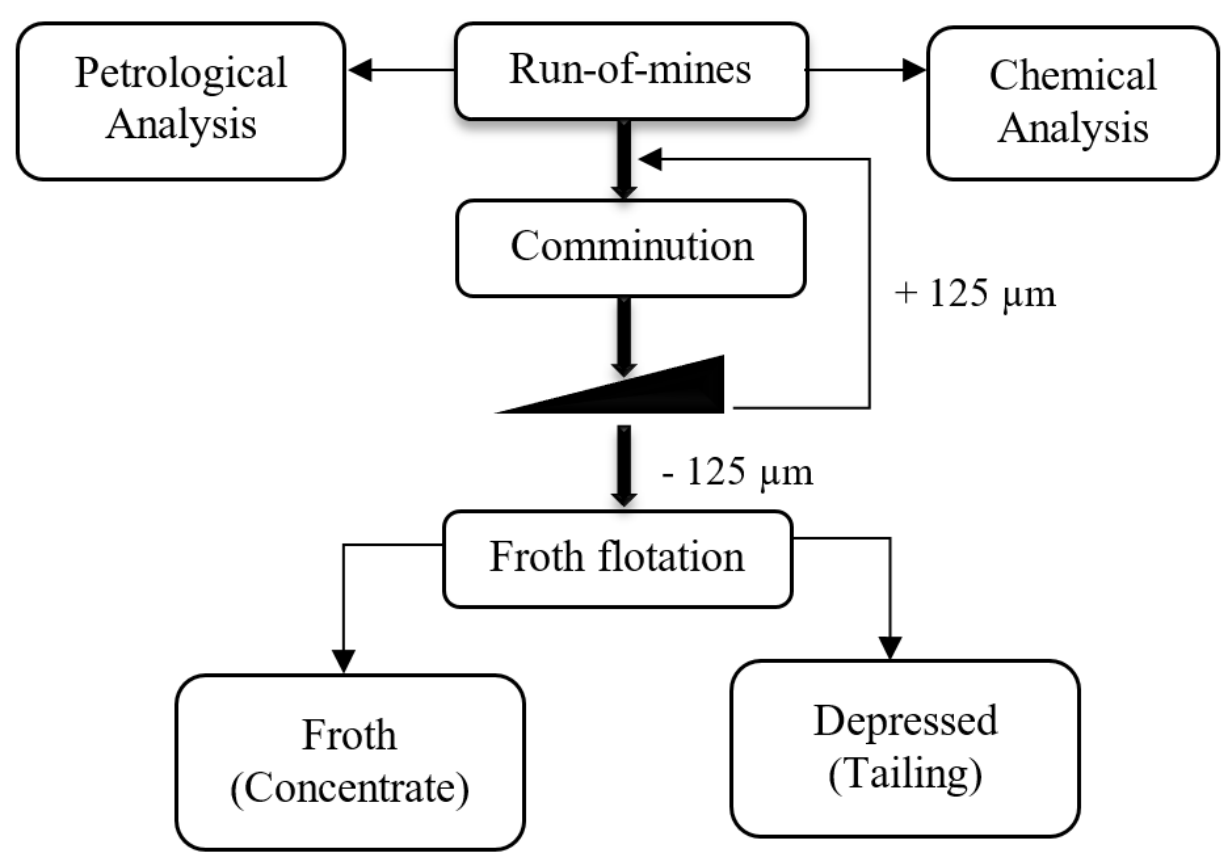

Figure 1: Typical process flowchart of the froth flotation of Itakpe iron ore 


\subsection{Compositional Analysis with Energy Dispersive X-ray Fluorescence (ED-XRF)}

Chemical constituents of the ore were appraised using Energy Dispersive $X$-ray Fluorescence Spectrometer (PANanalytical Minipal 7). Twenty grams $(20 \mathrm{~g})$ of the ore sample was finely ground to $100 \%$ passing 200 mesh and thereafter thoroughly mixed with cellulose flakes binder in the ratio of 5.0 $\mathrm{g}$ sample(s) to $1.0 \mathrm{~g}$ binder and pelletized at a pressure of 10-15 tons/square inch in a pelletizing machine. The pelletized samples were stored in a desiccator for analysis. ED-XRF machine was switched on and allowed to warm up for 2 hours. Finally, appropriate programs for the various elements of interest were employed to analyze the sample material(s) for their presence or absence. The result of the analysis was reported in percentage (\%) for the concentration of minor and major elements.

\subsection{Petrological Analysis}

Standard size rock samples were cut from the deposits after which their surfaces were ground using emery paper of grit size $500 \mu \mathrm{m}$ and $1000 \mu \mathrm{m}$ successively. The samples were mounted on a slide and viewed using a Leica Petrographic Microscope (Model: EGB $100 \mathrm{DMX}$ ) to reveal the ore's microstructure and inherent mineral constituents.

\subsection{Particle Size Analysis}

Fractional Sieve Analysis technique was adopted to ascertain the particle size distribution of the ore to determine its liberation size. Set of sieves were properly cleaned to avoid contamination of the mineral sample and arranged in conformity with $\sqrt{2}$ series ranging from $500-63 \mu \mathrm{m}$ [16]. $500 \mathrm{~g}$ crude sample was charged onto the upper sieve and the set of sieves were agitated for 30 minutes using an Automated Sieve Shaker (Model: Endecott AS400 control). After agitation, the sieves were separated and the retained on each sieve was weighed and recorded. The sieve fractions were also analyzed using ED-XRF.

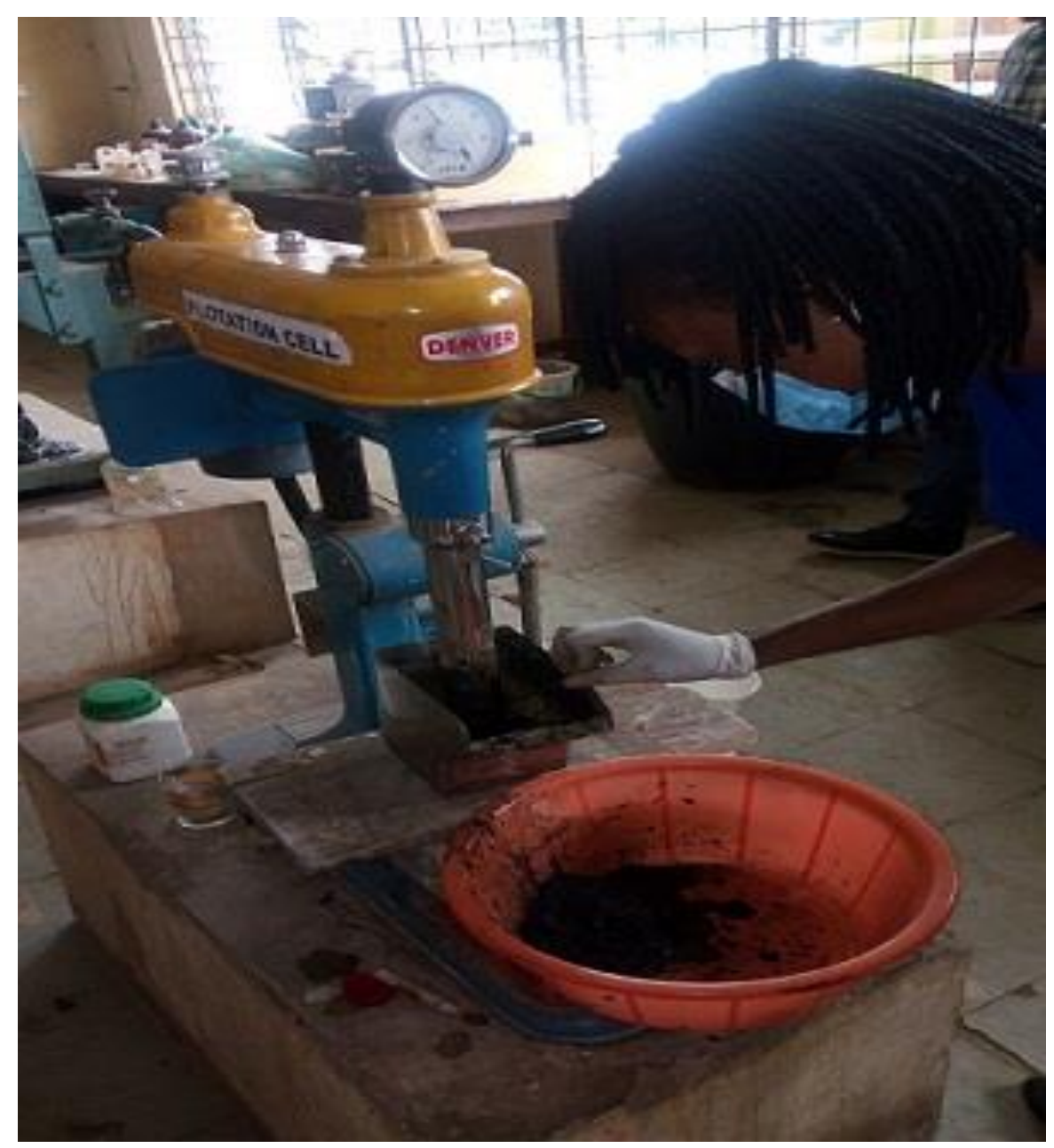

Plate 1: Denver Flotation Cell 


\subsection{Froth Flotation}

Laboratory flotation experiments were performed using a Denver Flotation Cell, Model: D-12 (Plate 1), having a capacity of up to $800 \mathrm{ml}$.

$100 \mathrm{~g}$ sample of $63 \mu \mathrm{m}$ fraction was charged into a $1000 \mathrm{ml}$ Pyrex cylinder containing up to $500 \mathrm{ml}$ of water under constant stirring speed (600 rpm) to prepare a slurry of $5 \%$ pulp density. The initial $\mathrm{pH}$ of the slurry was measured as 8.2 using a $\mathrm{pH}$ meter and then adjusted to 9 by adding a pH modifier (Sodium hydroxide). The slurry was agitated for 2 minutes after which 2 drops of corn starch (depressant) were added followed by further agitation for 2 minutes Then, 2 drops ( $2 \mathrm{~mm} / \mathrm{kg}$ ) of potassium amyl xanthate (PAX-collector) were added and further agitated for 2 minutes. The slurry was then transferred into the flotation cell. The later processes were repeated for the other collector types; sodium ethyl xanthate (SEX) and oleic acid. The impeller speed was set to $1000 \mathrm{rpm}$ and the slurry was further agitated for 2 minutes before adding 2 drops of methyl isobutyl carbinol (MIBC) into the slurry which serves as the frother; it gets adsorbed on the air-water interface and reduces surface tension to facilitate the formation stable air-bubbles. The total agitation time was 8 minutes per flotation process. The air valve of the flotation cell was then opened to introduce air into the slurry for about 30 seconds. This causes the formation of froth at the top layer of the slurry. The froth was then skimmed into trays after every 1 minute until no froth was formed. The above procedure was repeated at $\mathrm{pH}$ values of 10 and 11 . After which, other sized samples (75 $\mu \mathrm{m}$ and $125 \mu \mathrm{m}$ fractions) were also processed accordingly. The products (Froth and depressed) were filtered, dried, and randomly sampled for chemical analysis

\section{RESULTS AND DISCUSSION}

\subsection{Results}

The results obtained are presented in Tables 1-3 and Figures 2-6.

Table 1: Chemical composition of crude Itakpe iron ore deposit

\begin{tabular}{cccccccccc}
\hline Compounds & $\mathrm{Al}_{2} \mathrm{O}_{3}$ & $\mathrm{SiO}_{2}$ & $\mathrm{~K}_{2} \mathrm{O}$ & $\mathrm{CaO}$ & $\mathrm{V}_{2} \mathrm{O}_{5}$ & $\mathrm{MnO}$ & $\mathrm{Fe}_{2} \mathrm{O}_{3}$ & $\mathrm{CuO}$ & $\mathrm{ZnO}$ \\
\hline$\%$ composition & 4.20 & 53.05 & 0.24 & 0.559 & 0.008 & 0.068 & 36.18 & 0.034 & 0.006 \\
\hline
\end{tabular}

Table 2: Mineralogical Modal Analysis of Petrographic Slide of Itakpe Iron Ore

\begin{tabular}{ccccccc}
\hline \multirow{2}{*}{ Mineral } & \multicolumn{4}{c}{ No. of Counts } & \multirow{2}{*}{ Modal Count } \\
\cline { 2 - 5 } & $1^{\text {st }}$ View & $2^{\text {nd }}$ View & $3^{\text {rd }}$ View & Total & \\
\hline Quartz (Q) & 43 & 41 & 48 & 132 & 38 \\
Sillimanite & 10 & 1 & - & 11 & 3 \\
Haematite and other Opaque minerals $(\mathrm{H}, \mathrm{Op})$ & 67 & 65 & 68 & 200 & 59 \\
\hline Total & 120 & 107 & 116 & 343 & 100 \\
\hline
\end{tabular}




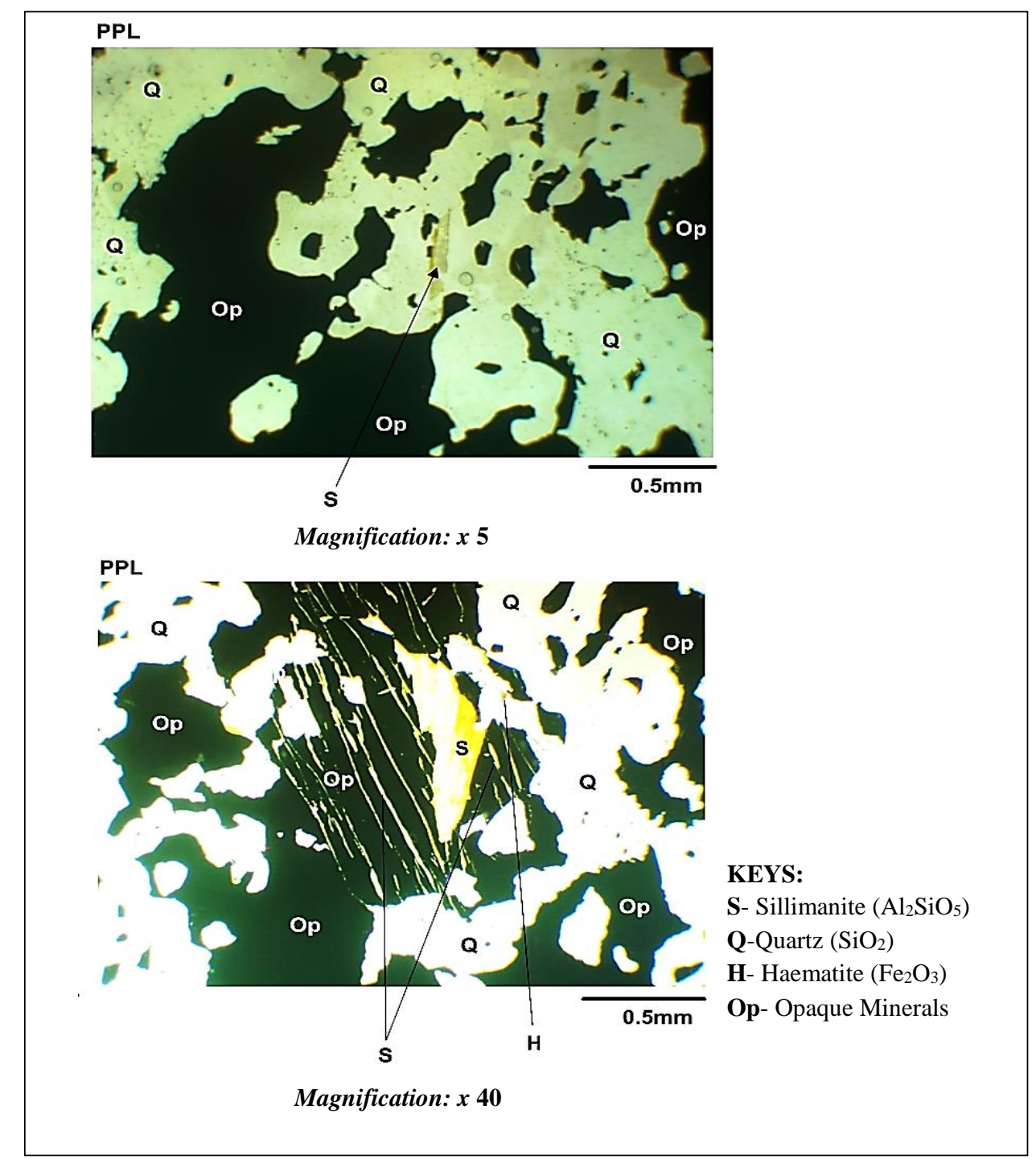

Figure 2: Photomicrographs of crude Itakpe iron ore sample with plane-polarized light

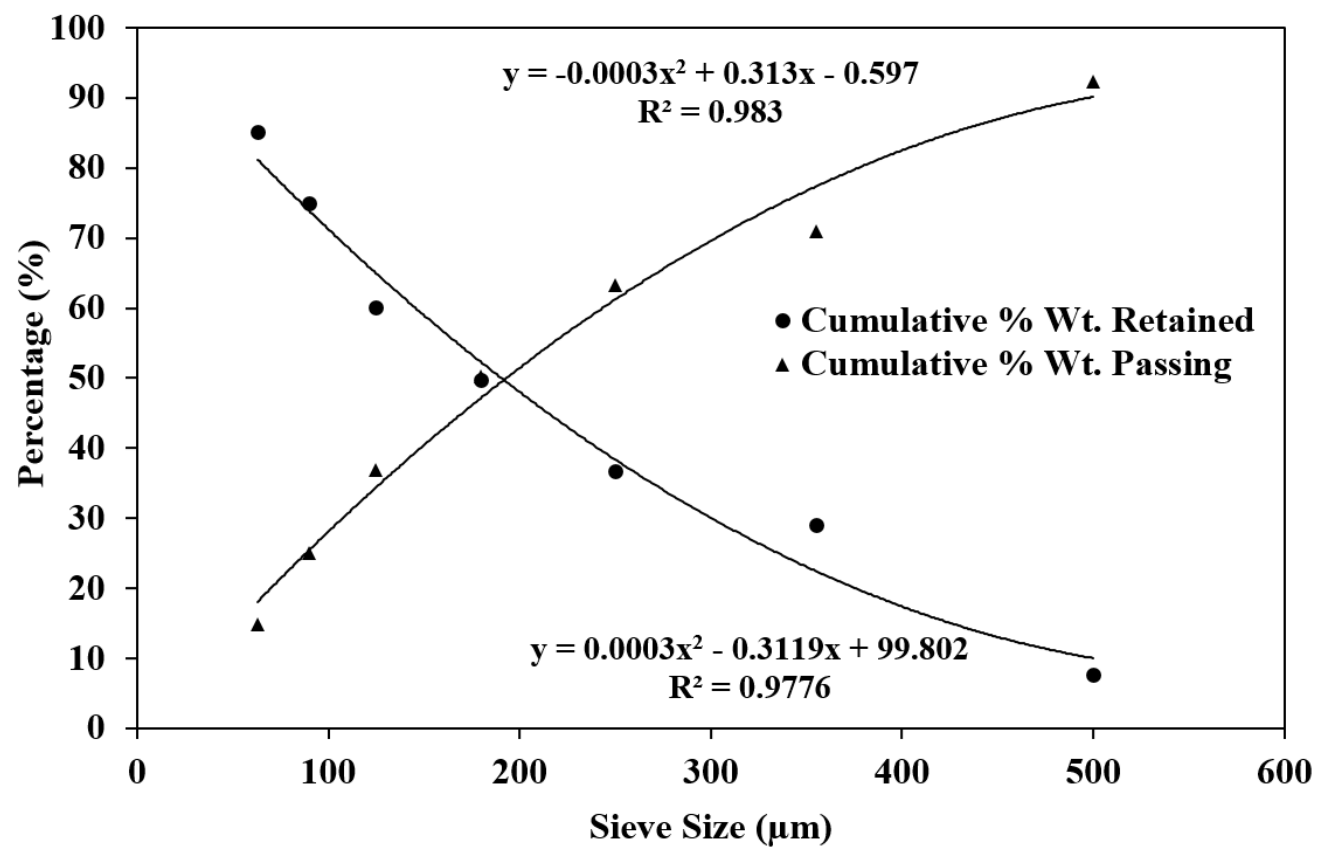

Figure 3: Graph showing the plot of \% cumulative weight retained and passing against sieve size for the sieve analysis of Itakpe iron ore 
Effects of Varied Process Parameters on Froth Flotation Efficiency: A Case Study of ItakPe Iron Ore, S. Akande, et al

Table 3: Fractional Sieve Size Analysis of Itakpe Iron Ore

\begin{tabular}{ccccccc}
\hline $\begin{array}{c}\text { Sieve Size } \\
\text { Range } \\
(\mu \mathrm{m})\end{array}$ & $\begin{array}{c}\text { Nominal } \\
\text { Aperture } \\
(\mu \mathrm{m})\end{array}$ & $\begin{array}{c}\text { Weight } \\
\text { Retained } \\
(\mathrm{g})\end{array}$ & $\begin{array}{c}\text { \% Weight } \\
\text { Retained }\end{array}$ & $\begin{array}{c}\text { \% Cumulative } \\
\text { Weight Retained }\end{array}$ & $\begin{array}{c}\text { \% Cumulative } \\
\text { Weight Passing }\end{array}$ & $\begin{array}{c}\% \\
\mathrm{Fe}_{2} \mathrm{O}_{3}\end{array}$ \\
\hline+500 & 500 & 38.50 & 7.70 & 7.70 & 92.30 & 35.10 \\
$-500+355$ & 355 & 106.40 & 21.28 & 28.98 & 71.02 & 26.34 \\
$-355+250$ & 250 & 38.35 & 7.67 & 36.65 & 63.35 & 20.20 \\
$-250+180$ & 180 & 65.50 & 13.10 & 49.75 & 50.25 & 15.81 \\
$-180+125$ & 125 & 66.45 & 13.29 & 63.04 & 36.96 & 12.83 \\
$-125+75$ & 75 & 59.40 & 11.88 & 74.92 & 25.08 & 43.91 \\
$-75+63$ & 63 & 50.90 & 10.18 & 85.09 & 14.91 & 11.06 \\
-63 & - & 74.55 & 14.91 & 100 & 0 & 20.56 \\
\hline
\end{tabular}

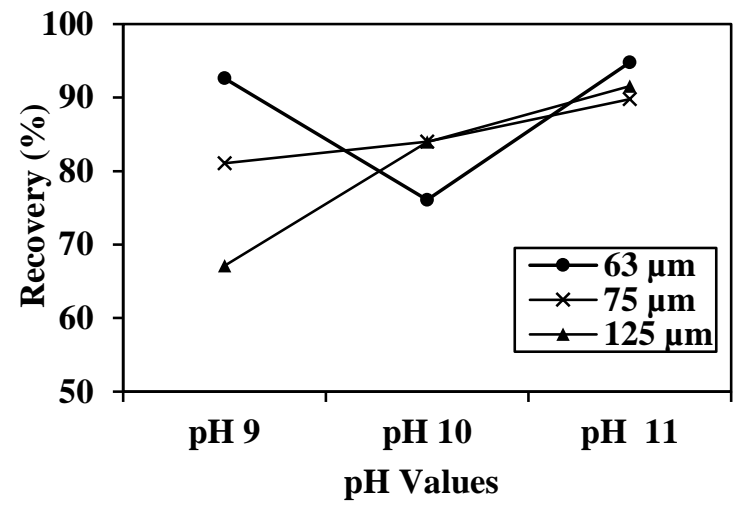

(a)

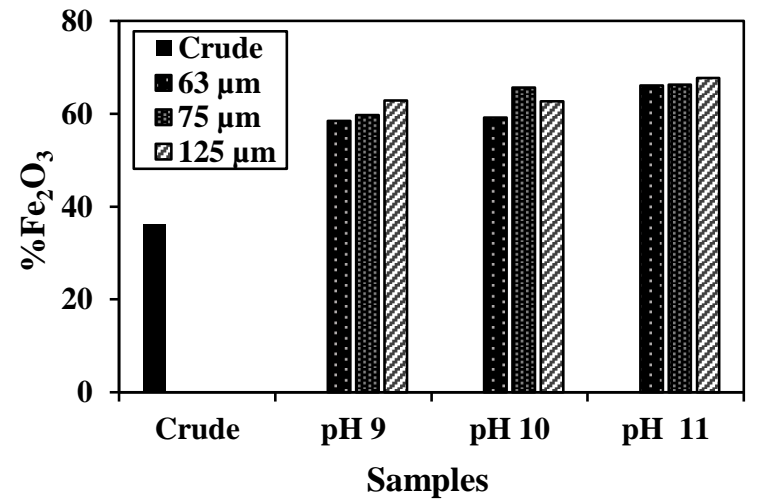

(b)

Figure 4: Graphs showing (a) recovery and (b) assay of iron concentrate at varied pH values and particle sizes for the flotation of Itakpe iron using PAX

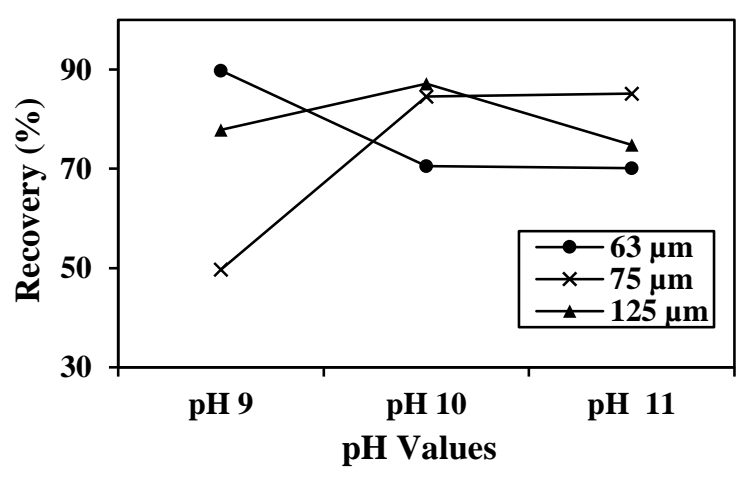

(a)

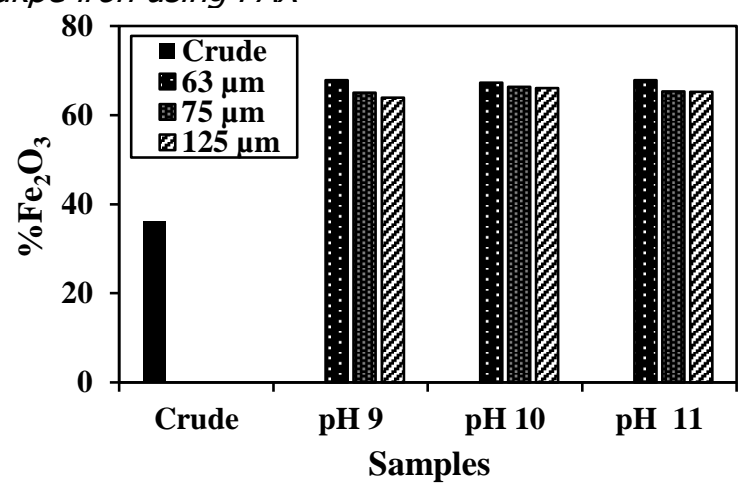

(b)

Figure 5: Graphs showing (a) recovery and (b) assay of iron concentrate at varying pH values and particle sizes for the flotation of Itakpe iron using SEX

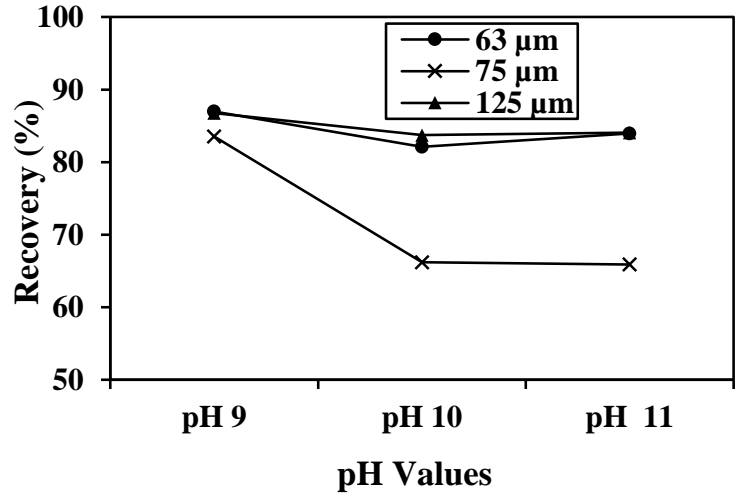

(a)

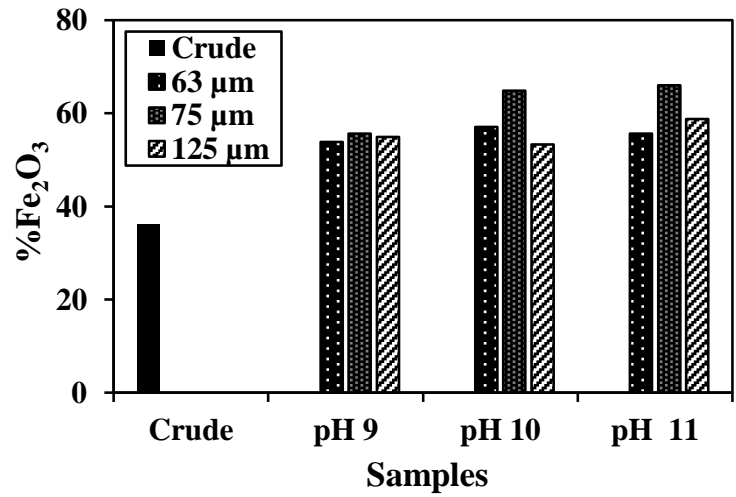

(b)

Figure 6: Graphs showing (a) recovery and (b) assay of iron concentrate at varying pH values and particle sizes for the flotation of Itakpe iron using Oleic acid 


\subsection{Discussion}

The compositional analysis of crude Itakpe iron ore is presented in Table 1. From the result, it can be deduced that the ore contains predominantly $36.18 \%$ $\mathrm{Fe}_{2} \mathrm{O}_{3}, 53.05 \% \mathrm{SiO}_{2}$, and $4.20 \% \mathrm{Al}_{2} \mathrm{O}_{3}$ alongside other trace compounds with negligible phosphorus content. It can be said that the mineral of interest $\left(\mathrm{Fe}_{2} \mathrm{O}_{3}\right)$ is embedded within a quartz dominated matrix, thus emphasizing the need for comminution to facilitate the complete liberation of mineral entities before processing. Therefore, it can be inferred that Itakpe iron ore is a lean non-acidic haematite rich ore assaying $36.18 \% \mathrm{Fe}_{2} \mathrm{O}_{3}$.

Petrological analysis results of Itakpe iron ore are presented in Figure 2 and Table 2; showing the photomicrographs and mineralogical modal analysis obtained respectively. It was deduced that the ore matrix contains coarsely packed grains of quartz $\left(\mathrm{SiO}_{2}\right)$, sillimanite $\left(\mathrm{Al}_{2} \mathrm{SiO}_{5}\right)$, haematite $\left(\mathrm{Fe}_{2} \mathrm{O}_{3}\right)$ /opaque minerals having a relative abundance of $38 \%, 3 \%$, and $59 \%$ respectively. The ore's photomicrographs further revealed the presence of specks of haematite (reddish-brown) within the rock which indicates a low degree of weathering that may not be visible with a simple eye observation. These findings tailor accordingly to the result of chemical analysis carried out, thus affirming that the ore is indeed predominated with haematite mineral and quartz as the major associated gangue.

Table 3 and Figure 3 reveal the size distribution of crude sample of Itakpe iron ore and a plot of \% cumulative weight retained and passing against sieve size respectively. From Table 3, it can be deduced that the ore particles are well distributed within the size range of $355-63 \mu \mathrm{m}$. This indicates that mineral particles embodied in the ore are nearly fine-sized which enhances the ore's amenability to froth flotation. The polynomial curves evident in Figure 3 are mirror images of each other having $R$ squared values $\left(R^{2}\right)$ of 0.983 and 0.9776 respectively. These values depict that the data closely fit the regression lines/models with an accuracy of $\sim 98 \%$; this value satisfies the standard $R$ squared value of $>75 \%$ which rates the significance of data for analysis [17]. Chemical analysis of each sieve fractions as shown in Table 3 revealed that the actual liberation size of the ore lies at $75 \mu \mathrm{m}$. This obtained particle size lies favourably within the size ranges suitable for effective separation by froth flotation documented in literatures $[8,14,18]$.
Figure 4 reveals the result obtained from the froth flotation of Itakpe iron ore using potassium amyl xanthate (PAX) in terms of percentage recovery and assay $\left(\% \mathrm{Fe}_{2} \mathrm{O}_{3}\right)$ at varying particle sizes and $\mathrm{pH}$ values. It can be deduced from Figure $4 a$ that an increment in \% recovery occurred as the $\mathrm{pH}$ value increases from 9 to 11 for all particle sizes. At pH 11, recoveries were $94.80 \%, 89.79 \%$, and $91.56 \%$ for 63 $\mu \mathrm{m}, 75 \mu \mathrm{m}$, and $125 \mu \mathrm{m}$ respectively. This implies that floating the ore using PAX in a more alkaline environment enhances \% recovery at fine feed sizes. Figure $4 \mathrm{~b}$ reveals a comparative analysis of the assay of the crude and concentrates obtained for all set-ofconditions. It can be deduced that the crude has been successfully enriched from $36.18 \% \mathrm{Fe}_{2} \mathrm{O}_{3}$ to a concentrate assaying averagely $65 \% \mathrm{Fe}_{2} \mathrm{O}_{3}$ via froth flotation using PAX. Also, a progressive increment of the concentrate assay was observed for all particle sizes as $\mathrm{pH}$ increases from 9 to 11 . At $\mathrm{pH} 11$, the assays obtained at feed sizes of 63,75 , and $125 \mu \mathrm{m}$ were $66.13 \%, 66.26 \%$, and $67.66 \% \mathrm{Fe}_{2} \mathrm{O}_{3}$ respectively. The assays obtained at this $\mathrm{pH}$ value were also considerably high relative to other $\mathrm{pH}$ values. Therefore, it can be inferred from these findings that processing of Itakpe iron ore using PAX at fine feed sizes $(<125 \mu \mathrm{m})$ and $\mathrm{pH} 11$ yields enriched concentrate assaying $67.66 \% \mathrm{Fe}_{2} \mathrm{O}_{3}$ at a recovery of about $92 \%$.

Figure 5 presents the result of recovery and assay of the mineral of interest $\left(\mathrm{Fe}_{2} \mathrm{O}_{3}\right)$ gotten from the froth flotation of Itakpe iron ore using sodium ethyl xanthate as collector at varying particle sizes and $\mathrm{pH}$ values. From Figure $5 a$, a somewhat erratic pattern was observed for recovery as $\mathrm{pH}$ increases from 9 to 11. At particle size of 63 and $125 \mu \mathrm{m}$, recovery reduces from $89.79-70.13 \%$ and $77.87-74.81 \%$ respectively, however, at $75 \mu \mathrm{m}$, recovery increases from $49.68-85.15 \%$ as the $\mathrm{pH}$ value increases from 9 to 11 . Figure $5 b$ shows the assay of concentrates obtained for all set-of-conditions. Likewise, significant enrichment of the crude ore from $36.18 \% \mathrm{Fe}_{2} \mathrm{O}_{3}$ to concentrate assaying about $66 \% \mathrm{Fe}_{2} \mathrm{O}_{3}$ was realized when processed with SEX. Also, no significant variation in concentrate assay was observed for all set-of-conditions. Therefore, it can be inferred that processing Itakpe iron ore using SEX is best carried out at $63 \mu \mathrm{m}$ and $\mathrm{pH} 9$ to yield concentrate assaying about $67.81 \% \mathrm{Fe}_{2} \mathrm{O}_{3}$ at a recovery of $89.79 \%$. From these findings, it is noteworthy that these values fall below those obtained when PAX was utilized, and also 
SEX nullifies the suitability of the ore to processing at $125 \mu \mathrm{m}$ but only at $63 \mu \mathrm{m}$. This implies that more energy will be expended to completely comminute the ore to $63 \mu \mathrm{m}$ compared to $125 \mu \mathrm{m}$, thus more cost is incurred which renders the process uneconomical.

Having processed the ore using oleic acid as collector, the obtained result is presented in Figure 6 . Figure $6 a$ shows the trend of recovery for different particle sizes as the $\mathrm{pH}$ value increases from 9 to 11 while Figure $6 \mathrm{~b}$ also reveals the assay of concentrates obtained for all set-of-conditions relative to that of the crude. A progressive reduction in \% recovery was observed as the $\mathrm{pH}$ value increases from 9 to 11 for all particle sizes. This implies that the processing of Itakpe iron ore using oleic acid yields less recovery as the pulp becomes more alkaline. This can be ascribed to the neutralization reaction occurring between the collector and the alkaline pulp which mitigates the ability of the collector to make the mineral of interest more hydrophobic. This phenomenon is very common with acidic collectors which limit their usage in alkaline pulp, rather they are employed in an acidic environment where neutralization effect is negligible [19]. From Figure $6 \mathrm{~b}$, it is quite obvious that significant enrichment of the crude ore from $36.18 \%$ $\mathrm{Fe}_{2} \mathrm{O}_{3}$ to concentrate assaying averagely $55 \% \mathrm{Fe}_{2} \mathrm{O}_{3}$ was achieved. Also, a progressive increase in assay was obtained for all particle sizes as the $\mathrm{pH}$ value increases from 10 to 11 . From these findings, the inverse relationship between percent recovery and concentrate assay can be established. Moreso, processing at $\mathrm{pH} 9$ for all particle sizes yielded optimal recoveries. Therefore, it can be inferred that processing of Itakpe iron ore using oleic acid at $\mathrm{pH} 9$ and particle sizes below $125 \mu \mathrm{m}$ yields enriched concentrate assaying averagely $57.8 \% \mathrm{Fe}_{2} \mathrm{O}_{3}$ at a recovery of $85 \%$. However, it is noteworthy that these values fall below those obtained for PAX and SEX.

\section{CONCLUSION}

The suitability of Itakpe iron ore to froth flotation at varying process parameters has been investigated and conclusions drawn include:

i. Itakpe iron ore is a low-grade ore assaying about $36.18 \% \quad \mathrm{Fe}_{2} \mathrm{O}_{3}$ and contains predominantly quartz and haematite minerals within its matrix. Also, the ore's liberation size lies favourably at $75 \mu \mathrm{m}$. ii. Significant enrichment was actualized when the ore was processed using PAX, SEX, and oleic acid at varying particle sizes and $\mathrm{pH}$ values.

iii. Also, froth flotation efficiency was observed to vary with respect to the collector used such that floating the ore using PAX gave the best result.

iv. Processing the ore using $\mathrm{PAX}$ at $\mathrm{pH} 11$ and fine feed size $(<125 \mu \mathrm{m})$ was established as the best process condition yielding optimal recovery of about $92 \%$ at a concentrate grade of $67.66 \% \mathrm{Fe}_{2} \mathrm{O}_{3}$.

On-premise of these findings, further pilot-scale investigation using this established condition is recommended to derive more data towards the industrial production of enriched Itakpe iron ore concentrates meet for iron smelting operation.

\section{REFERENCES}

[1]. Cook, N.J. "Mineral Characterisation of Industrial Minerals Deposits at the Geological Survey of Norway: A Short Introduction", Norges Geologist Undersøkelse Bulletin, vol. 436, 2000, pp. 189-192.

[2]. Hope, G. A., Woodsy, R. and Munce, C. G. "Raman Microprobe Mineral Identification", Mineral Engineering, vol. 14 (12), 2001, pp. 1565-1577.

[3]. Ayingayure, A. C Characterisation of Iron Ore-A Case Study of Mount Tokadeh, Western Nimba Area, Liberia (Master Thesis), Retrieved from Kwame Nkrumah University of Science and Technology Database, 2014

[4]. Gaudin, A.M. Flotation, McGraw-Hill, New York, 1957

[5]. Fuerstenau, M. C., Miller, J. D., and Kuhn, M. C. Chemistry of Flotation, Society of Mining Engineers, AIME, New York, 1985

[6]. Metso Basics in Minerals Processing, 5th Edition, Metso Minerals, 2006

[7]. Glembotskii, V. A., Klassen, V. I., and Plaksin, I. N. Flotation, Primary Sources, New York, 1972

[8]. Wills, B. A. and Napier-Munn, T. J. Mineral Processing Technology, 7th ed., Pergamon Press, Oxford, 2006

[9]. Bamalli, U. S., Moumouni, A. and Chaanda, M.S. () "A Review of Nigerian Metallic Minerals for Technological Development", Natural Resources, vol. 2: 2011, pp. $87-91$. 
[10].Klassen, V. I., and Mokrousov, V. A. $A n$ Introduction to the Theory of Flotation (translated by J. Leja and G. W. Poling), Butterworths, London, 1963

[11]. Akinrinsola, E. O. and Adekeye, J. I. "A Geostatistical Ore Reserve Estimation of the Itakpe Iron Ore Deposit Okene, Kogi State", J. Min. Geol., vol. 20(1), 1993, pp. 19-25.

[12]. Ameh, E.G. "Geochemical Distribution of Heavy Metals in Soil around Itakpe Iron-ore Mining Area-A Statistical Approach", Research Journal of Environmental and Earth Sciences, vol. 6 (3), 2014, pp.118-126.

[13]. NIOMC Project Report, vol. 2, 1980, pp. 1-10.

[14]. Yan, D. and Gupta, A. Mineral Processing Design \& Operation: An Introduction. Elsevier Publisher, Netherlands, 2006

[15].Araujo, A.C., Viana, P.R.M., and Peres, A.E.C. "Reagents in iron ores flotation", Mineral Engineering, vol. 18, 2005, pp. 219-224.

[16]. Olatunji, T. A., Alabi, O. O., Gbadamosi, Y. E., and Ola-Omole, O. O. "Susceptibility of Akure
South Mineral to Magnetic and Gravity Separation: A Research Geared Towards Sustainability via Exploration and Exploitation of Solid Minerals" Proceedings of $33^{\text {rd }}$ Annual Conference of the Nigerian Metallurgical Society (NMS) held at the Petroleum Training Institute, Effurum, Delta State, October 31 $1^{\text {st-November }}$ $3^{\text {rd }}, 2017$, pp. 37-45.

[17].Patricia M., Jose I., Cesar G., and Oscar P. "Assessing data analysis performance in research contexts: An experiment on accuracy, efficiency, productivity, and researchers' satisfaction", Data \& Knowledge Engineering, vol. 116, 2018, pp. 177-204.

[18]. Neymayer, P. L., George, E. S., and Antônio, E. $\mathrm{K}$. "Effect of particle size range on iron ore flotation", REM: R. ESC. Minas, Ouro Preto, vol. 66(2), 2013, pp. 251-256.

[19]. Richard, R. Klimp Froth Flotation, Encyclopedia of Physical Science and Technology (Third Edition), 2003, pp. 219-234. 